\title{
Effect of hygroscopicity of the metal salt on the formation and air stability of lyotropic liquid crystalline mesophases in hydrated salt-surfactant systems
}

\author{
Cemal Albayrak, Gözde Barım, Ömer Dag* \\ Bilkent University, Department of Chemistry, 06800 Ankara, Turkey
}

\section{A R T I C L E I N F O}

\section{Article history:}

Received 1 May 2014

Accepted 7 July 2014

Available online 15 July 2014

\section{Keywords:}

Lyotropic liquid crystal

Deliquescence

Lithium salts

Hygroscopicity

Surfactants

\begin{abstract}
A B S T R A C T
It is known that alkali, transition metal and lanthanide salts can form lyotropic liquid crystalline (LLC) mesophases with non-ionic surfactants (such as $\mathrm{C}_{i} \mathrm{H}_{2 i+1}\left(\mathrm{OCH}_{2} \mathrm{CH}_{2}\right)_{j} \mathrm{OH}$, denoted as $\mathrm{C}_{i} \mathrm{E}_{j}$ ). Here we combine several salt systems and show that the percent deliquescence relative humidity (\%DRH) value of a salt is the determining parameter in the formation and stability of the mesophases and that the other parameters are secondary and less significant. Accordingly, salts can be divided into 3 categories: Type I salts (such as $\mathrm{LiCl}, \mathrm{LiBr}, \mathrm{LiI}, \mathrm{LiNO}_{3}, \mathrm{LiClO}_{4}, \mathrm{CaCl}_{2}, \mathrm{Ca}\left(\mathrm{NO}_{3}\right)_{2}, \mathrm{MgCl}_{2}$, and some transition metal nitrates) have low \%DRH and form stable salt-surfactant LLC mesophases in the presence of a small amount of water type II salts (such as some sodium and potassium salts) that are moderately hygroscopic form disordered stable mesophases, and type III salts that have high \%DRH values, do not form stable LLC mesophases and leach out salt crystals. To illustrate this effect, a large group of salts from alkali and alkaline earth metals were investigated using XRD, POM, FTIR, and Raman techniques. Among the different salts investigated in

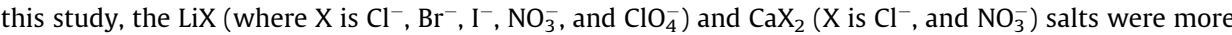
prone to establish LLC mesophases because of their lower \%DRH values. The phase behavior with respect to concentration, stability, and thermal behavior of $\mathrm{Li}(\mathrm{I})$ systems were investigated further. It is seen that the phase transitions among different anions in the Li(I) systems follow the Hofmeister series.
\end{abstract}

(c) 2014 Elsevier Inc. All rights reserved.

\section{Introduction}

Oligo(ethylene oxide) type surfactant molecules $\left(\mathrm{C}_{n} \mathrm{H}_{2 n+1}\left(\mathrm{OCH}_{2-}\right.\right.$ $\left.\mathrm{CH}_{2}\right)_{m} \mathrm{OH}$ denoted as $\mathrm{C}_{i} \mathrm{E}_{j}$ ) form lyotropic liquid crystalline (LLC) mesophases with water [1], ionic liquids [2], supercritical carbon dioxide [3,4], organic solvents [5-7], and molten hydrated salts [8-11]. The molten hydrated salts are usually divalent transition metal or lanthanide aqua complexes that have melting points close to room temperature (RT). The hydrogen bonding interactions between the coordinated water molecules and ethylene oxide units of the surfactant play an important role in the self-assembly process. In addition to molten hydrated transition metal and lanthanide salt [12], the hydrated lithium salts ( $\mathrm{LiX} \cdot \mathrm{nH}_{2} \mathrm{O}-\mathrm{C}_{12} \mathrm{E}_{10}$ systems) also exhibit LLC mesophases at very high salt and very low water concentrations [10], where the salt-water couple collaboratively acts as the solvent component in the system. In these highly concentrated systems water molecules are responsible for the hydration of the ions in the LLC mesophase and the water/salt mole

\footnotetext{
* Corresponding author.

E-mail address: dag@fen.bilkent.edu.tr (Ö. Dag).
}

ratio can be as low as 2 [10]. We refer to such mesophases as saltsurfactant systems in order to distinguish them from the systems at low salt concentrations, where the solvent is merely water rather than the salt-water couple. To the best of our knowledge, the effect of electrolytes on the $\mathrm{H}_{2} \mathrm{O}-\mathrm{C}_{i} \mathrm{E}_{j}$ mesophases has been investigated only at low salt concentrations and the salt species were considered as an additive in the mesophase [13-22].

The behavior of the mesophases at high salt concentrations is significantly different and complex as compared to binary $\mathrm{H}_{2} \mathrm{O}-\mathrm{C}_{i-}$ $\mathrm{E}_{j}$ systems $[10-11,23]$. In the salt-surfactant systems the interactions between the solvent (salt + water) and the surfactant are stronger because of the higher acidity of the coordinated water in the medium. The strong interactions lead to higher stability at both high and low temperatures [11] and may also lead to the emergence of more complex mesocrystalline phases [23]. Moreover, the LC phases of salt-surfactant systems are stable under open atmospheric conditions, while in the $\mathrm{H}_{2} \mathrm{O}-\mathrm{C}_{i} \mathrm{E}_{j}$ systems the water molecules loosely hydrate the surfactant head groups and are prone to water evaporation. Understandably, the phase behavior of the salt-surfactant system significantly depends on the salt species and each salt-surfactant system may exhibit its unique 
phase behavior. For instance, the meso-crystalline phases are observed only in LiI, and some $\mathrm{Ca}$ (II) and $\mathrm{Mg}$ (II) salts [23].

We believe that in such a complex and unexplored area it is important to present a general behavioral study of different saltsurfactant systems (under open atmospheric conditions), that is their LLC mesophase formation tendencies. This kind of a study can also be very helpful for those who would like to use the saltsurfactant LLC systems as medium for material synthesis. In our experiments with many different salts, we observed that some salts are more prone to form LLC phases while others quickly leach out salt crystals or stay as disordered mesophases. Usually, the coordinated/hydration waters are non-volatile at very low relative humidity $(\mathrm{RH})$ levels $(10 \% \mathrm{RH})$ and they are stable for short timescales even under a few mbar vacuum conditions. However, the strength of the hydration (or the hydration energy) is not the only determining parameter. For example the $\mathrm{LiF} \cdot \mathrm{nH}_{2} \mathrm{O}-\mathrm{C}_{i} \mathrm{E}_{j}$ systems are unable to form LLC mesophases because of the very low solubility of the $\mathrm{LiF}$ in water. Other parameters are also important such as the strength of the cation $\cdots \mathrm{H}_{2} \mathrm{O} \cdots \mathrm{C}_{i} \mathrm{E}_{j}$ and the cation $\cdots \mathrm{C}_{i} \mathrm{E}_{j}$ interactions (valence of the cation), and the position of the anion in the Hofmeister series [24]. Nevertheless, we have found out that most of these effects can be summarized by the percent deliquescence relative humidity (\%DRH) value of the salt. The \%DRH is defined as the percent relative humidity of the surrounding atmosphere at which the material begins to absorb moisture. Therefore, low \%DRH means the salts dissolve by absorbing water from the surrounding at lower humidity. Another words, the deliquescence occurs at a critical relative humidity, where a salt spontaneously dissolves by absorbing the ambient water from the air. If the equilibrium vapor pressure of water in a saturated solution is lower than the vapor pressure of water in the air, the salt spontaneously absorbs water from the air until a thermodynamic equilibrium is established. The saturated solutions of such salts are expected to be stable above their \%DRH value, see Table 1 . To summarize, the tendency of the salt to retain the water is reflected on its \%DRH value. We observed that this is also true when the salt species is in the LC mesophase.
In this investigation, we demonstrate that the salts with low \%DRH values are more prone to form LLC mesophases in the salt. $\mathrm{nH}_{2} \mathrm{O}$-surfactant systems. Note also that without water, the salt- $\mathrm{C}_{i} \mathrm{E}_{j}$ systems do not form an LLC mesophase unless the melting point of the salt is around RT, and without salts the $\mathrm{C}_{12} \mathrm{E}_{10}-\mathrm{H}_{2} \mathrm{O}$ system is unstable under our experimental conditions, because the water evaporates and leaves the system. A large group of salts has been studied over a broad range of salt concentrations, their general tendencies are outlined and their compatibility with the salts \%DRH value is presented. The salt-surfactant mesophases need to be further investigated to enable the synthesis of new porous materials [30,31] and as ion membranes [10]. This investigation has been carried out using thin films of the spin coated solutions (salt- $\mathrm{C}_{i} \mathrm{E}_{j}$ in excess water) or gels (hydrated salt- $\mathrm{C}_{12} \mathrm{E}_{10}$ ), and characterizations were done using $\mathrm{X}$-ray diffraction (XRD), polarized optical microscopy (POM), Fourier Transform-Infrared (FT-IR) and Raman spectroscopy techniques.

\section{Materials and methods}

\subsection{Materials}

Tap water was distilled and deionised using a Millipore Synergy 185 water purifier and used without further treatment. Other chemicals were obtained from the following companies and used without further treatment: Sigma Aldrich: $\mathrm{LiBr}, \mathrm{LiCl}, \mathrm{LiNO}_{3}, \mathrm{LiClO}_{4}$, $\mathrm{KSCN}, \mathrm{KCl}, \mathrm{KClO}_{4}, \mathrm{KNO}_{3}, \mathrm{NaI}, \mathrm{NaCl}, \mathrm{NaNO}_{3}, \mathrm{NaSCN}, \mathrm{NaClO}_{4}$, $\mathrm{Ca}\left(\mathrm{NO}_{3}\right)_{2} \cdot 4 \mathrm{H}_{2} \mathrm{O}, \mathrm{C}_{12} \mathrm{E}_{18}, \mathrm{C}_{12} \mathrm{E}_{10}$, and $\mathrm{CH}_{3} \mathrm{COONa}$. Merck: $\mathrm{NaBr}$, $\mathrm{Mg}\left(\mathrm{NO}_{3}\right)_{2} \cdot 6 \mathrm{H}_{2} \mathrm{O}, \mathrm{KI}$, and $\mathrm{CaCl}_{2} \cdot 6 \mathrm{H}_{2} \mathrm{O}$. Riedel-de Haen: $\mathrm{MgCl}_{2} \cdot 6 \mathrm{H}_{2} \mathrm{O}$.

\subsection{Preparation of the LLC gel samples}

The LLC gel samples were directly prepared by mixing the required weight of the ingredients without further treatment. This procedure allows definite control and knowledge of the amount of the ingredients. Some samples of $\mathrm{LiCl} \cdot \mathrm{nH}_{2} \mathrm{O}-\mathrm{C}_{12} \mathrm{E}_{10}, \mathrm{LiClO}_{4} \cdot \mathrm{nH}_{2} \mathrm{O}-$ $\mathrm{C}_{12} \mathrm{E}_{10}$ and $\mathrm{H}_{2} \mathrm{O}-\mathrm{C}_{12} \mathrm{E}_{10}$ were also prepared in this way. The

Table 1

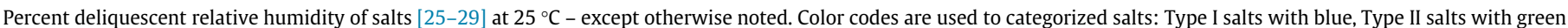
and Type III salts with red color. Other salts were not investigated except $\mathrm{NaOH}$ which is air reactive.

\begin{tabular}{|c|c|c|c|}
\hline Salt & \%DRH [25] & $\underline{\text { Salt }}$ & \%DRH [25] \\
\hline $\mathrm{H}_{2} \mathrm{O}$ & 100 & $\mathrm{NaBr}$ & 57.0 \\
\hline $\mathrm{K}_{2} \mathrm{SO}_{4}$ & 100 & $\mathrm{NaBr}-\mathrm{KBr}$ mixture & 56.0 \\
\hline $\mathrm{KClO}_{3}$ & 98.0 & $\mathrm{C}_{6} \mathrm{H}_{12} \mathrm{O}_{6} \cdot 1 / 2 \mathrm{H}_{2} \mathrm{O}$ & $55.0\left(27^{\circ} \mathrm{C}\right)$ \\
\hline $\mathrm{CaHPO}_{4} \cdot 2 \mathrm{H}_{2} \mathrm{O}$ & 97.0 & $\mathrm{NH}, \mathrm{Cl}-\mathrm{NaBr}$ misture & 54.0 \\
\hline $\mathrm{KH}_{2} \mathrm{PO}_{4}$ & 96.6 & $\mathrm{NaNO} 3,-\mathrm{KBr}$ mixture & 54.0 \\
\hline $\mathrm{KNO}_{3}$ & $95.0-91.0$ & $\mathrm{Mg}\left(\mathrm{NO}_{3}\right)_{2} \cdot 6 \mathrm{H}_{2} \mathrm{O}$ & $52.0\left(24.5^{\circ} \mathrm{C}\right)$ \\
\hline $\mathrm{NH}_{4} \mathrm{H}_{2} \mathrm{PO}_{4}$ & 93.0 & $\mathrm{Ca}\left(\mathrm{NO}_{3}\right)_{2} \cdot 4 \mathrm{H}_{2} \mathrm{O}$ & 51.0 \\
\hline $\mathrm{Na}_{2} \mathrm{C}_{2} \mathrm{H}_{4} \mathrm{O}_{6} \cdot 2 \mathrm{H}_{2} \mathrm{O}$ & 92.0 & $\mathrm{NaClO}_{4}$ & $43-46[27,28]$ \\
\hline $\mathrm{ZnSO}_{4} .7 \mathrm{H}_{2} \mathrm{O}$ & 88.5 & $\mathrm{~K}_{2} \mathrm{CO}_{3} \cdot 2 \mathrm{H}_{2} \mathrm{O}$ & 43.0 \\
\hline $\mathrm{BaCl}_{2} \cdot 2 \mathrm{H}_{2} \mathrm{O}$ & $88.0\left(24.5^{\circ} \mathrm{C}\right)$ & $\mathrm{NaI}$ & 38.17 [26] \\
\hline $\mathrm{Na}_{2} \mathrm{CO}_{3} \cdot 10 \mathrm{H}_{2} \mathrm{O}$ & 87.0 & $\mathrm{MgCl}_{2} \cdot 6 \mathrm{H}_{2} \mathrm{O}$ & 33.0 \\
\hline KCl & $89.0-84.5$ & $\mathrm{CaCl}_{2} \cdot 6 \mathrm{H}_{2} \mathrm{O}$ & 31.0 \\
\hline $\mathrm{C}_{12} \mathrm{H}_{22} \mathrm{O}_{17}$ & 85.0 & $\mathrm{CH}_{3} \mathrm{COOK}$ & 19.0 \\
\hline$\left(\mathrm{NH}_{4}\right) \mathrm{SO}_{4}$ & $83.0-81.1$ & LiI & $17.56[26]$ \\
\hline $\mathrm{KBr}$ & 79.0 & $\left(\mathrm{CH}_{3} \mathrm{COO}\right)_{2} \mathrm{Ca} . \mathrm{H}_{2} \mathrm{O}$ & 17.0 \\
\hline $\mathrm{NH}_{4} \mathrm{Cl}$ & $79.3-77.0$ & $\mathrm{LiCl} \cdot \mathrm{H}_{2} \mathrm{O}$ & 13.0 \\
\hline $\mathrm{CH}_{3} \cdot \mathrm{COONa}$ & 77.0 & $\mathrm{LiNO}_{3}$ & $12.86[29]$ \\
\hline $\mathrm{CO}\left(\mathrm{NH}_{2}\right)_{2}$ & $76.7-76.0$ & $\mathrm{H}_{3} \mathrm{PO}_{4} \cdot 1 / 2 \mathrm{H}_{2} \mathrm{O}$ & 9.0 \\
\hline $\mathrm{NaCl}$ & $76.5-75.0$ & $\mathrm{NaOH}$ & 6.5 \\
\hline $\mathrm{NaNO}_{3}$ & $76.0-74.0$ & $\mathrm{LiBr}$ & $6.37[28]$ \\
\hline $\mathrm{K}_{2} \mathrm{C}_{4} \mathrm{H}_{4} \mathrm{O}_{6} \cdot 1 / 2 \mathrm{H}_{2} \mathrm{O}$ & 75.0 & $\mathrm{P}_{2} \mathrm{O}_{5}$ & 0.0 \\
\hline $\mathrm{LiClO}_{4}$ & $\sim 70[28]$ & & \\
\hline KI & $68.86[26]$ & & \\
\hline $\mathrm{NH}_{4} \mathrm{NO}_{3}$ & 63.5 & & \\
\hline
\end{tabular}


samples were prepared at different compositions by keeping the amount of the surfactant weight constant at $1.0 \mathrm{~g}$. If one wants to scale up the preparation, further treatments may be necessary. These procedures were optimized only for $1.0 \mathrm{~g} \mathrm{C}_{12} \mathrm{E}_{10}$. For instance, if $2.0 \mathrm{~g}$ of $\mathrm{C}_{12} \mathrm{E}_{10}$ is used one may observe some salt crystallization because of the insufficient homogeneity.

For example, in preparation of $3 \mathrm{LiNO}_{3} \cdot 3 \mathrm{H}_{2} \mathrm{O}-1 \mathrm{C}_{12} \mathrm{E}_{10}$ sample (numbers depict the mole ratios), $0.330 \mathrm{~g}$ of $\mathrm{LiNO}_{3}, 0.258 \mathrm{~g}$ of $\mathrm{H}_{2} \mathrm{O}$ and $1.000 \mathrm{~g}$ of $\mathrm{C}_{12} \mathrm{E}_{10}$ were weighted and mixed in a $20 \mathrm{ml}$ glass vial. The cap of the vial was then tightly sealed with a Teflon band. The sample was constantly shaken in a water bath above the melting point of the composition for $24 \mathrm{~h}$ in order to complete the homogenization. A homogeneous monophase sample should never be opaque or contain salt crystals. All other gel phases were prepared using the same method.

\subsection{Preparation of the samples in solution phase}

The solution phase preparation does not require heating. The required weights of the ingredients were mixed in glass vials and stirred for $6 \mathrm{~h}$. For instance, in preparing the $2.0 \mathrm{CaCl}_{2}-1.0 \mathrm{C}_{12} \mathrm{E}_{10}$ aqueous solution, $0.700 \mathrm{~g}$ of $\mathrm{CaCl}_{2} \cdot 6 \mathrm{H}_{2} \mathrm{O}, 1.0 \mathrm{~g}$ of $\mathrm{C}_{12} \mathrm{E}_{10}$ and $5 \mathrm{ml}$ of $\mathrm{H}_{2} \mathrm{O}$ were mixed and stirred $6 \mathrm{~h}$ for homogenization. The solutions were then ready for further treatment.

\subsection{Preparation of LLC thin films}

The LLC thin films were prepared by spin coating the homogenized solutions on glass slides or silicon wafers. A few drop of the above solution was put on a substrate installed on the spin coater and then spun at 750 or $1000 \mathrm{rpm}$ depending on the experimental method. The samples were prepared as a gel using appropriate amount of water or as a clear solution using excess amount of water. The solutions can be spin coated or casted over various substrates for further investigation. The spin coated samples are more homogeneous compared to casted films due to the rapid evaporation of the excess water. Slow evaporation of water in drop casted samples creates a concentration gradient. Additionally, if the samples are not stable under an open atmosphere the dropped samples will equilibrate more slowly. For instance, the instant crystallization of salt can be detected for spin coated samples, while in drop casted samples the crystallization may take several hours or even days. After the spin coating process, the samples were allowed to equilibrate under ambient conditions (room temperature (RT) and 20-25 \%RH) before performing any measurements. The stability of the samples was followed for days under this condition to monitor the presence of any salt crystals. The optical microscopy is a powerful technique to monitor the existence of small amounts of salt crystals as compared to XRD. The water content of the spin coated samples depends on the amount and type of the salt in the samples and the \% RH. The fresh samples were generally in their LLC mesophases, and their structures depend on the type and concentration of the salt species.

\subsection{Instrumentation and measurements}

The XRD patterns were recorded on a Rigaku Miniflex Diffractometer using a high power $\mathrm{Cu} \mathrm{K \alpha}$ source operating at $30 \mathrm{kV} /$ $15 \mathrm{~mA}$ and a wavelength of $1.5405 \AA$. The samples were either spin coated over glass slides from the homogeneous solutions at $1000 \mathrm{rpm}$ or spread over a glass sample holders. The measurements were made with a 0.01 or $0.02^{\circ}$ intervals and $0.1-5 \% \mathrm{~min}$ scan speed. The samples are rotated at different angles to monitor any hidden diffraction lines due to the orientation of the LLC mesophase. The POM images were obtained in transmittance mode using a ZEISS Axio Scope.A1 Microscope with a Linkam LTS350 temperature controlling stage attached to the microscope. Temperature control was done using a Linkam T95-LinkPad temperature programmer attached to the stage. For heating and cooling measurements the samples were sandwiched between two glass slides to avoid water evaporation. The cooling is achieved by computer controlled pumping of the chamber with liquid nitrogen. The heating-cooling rates were varied between 1 and $5 \% \mathrm{~min}$. The images were captured and the heating and cooling processes were monitored using a camera attached on top of the microscope. The FT-IR spectra were recorded using Bruker Tensor 27 model FTIR spectrometer. A Digi Tect TM DLATGS detector was used with a resolution of $4.0 \mathrm{~cm}^{-1}$ in the $400-4000 \mathrm{~cm}^{-1}$ range. The samples were either spin coated on IR transparent Si substrates, from homogeneous solutions at $750 \mathrm{rpm}$, or spread as a thin layer from a gel sample. The samples were sandwiched between two silicon wafers and taped if the water content was to be analyzed. The resolution of the instrument was kept at $4 \mathrm{~cm}^{-1}$ for all measurements and the number of scans was varied between 8 and 512 . The micro-Raman spectra were recorded on a LabRam confocal Raman microscope with a $300 \mathrm{~mm}$ focal length. The spectrometer is equipped with a Ventus LP $53250 \mathrm{~mW}$, diodepumped solid-state laser operated at $20 \mathrm{~mW}$, with a polarization ratio of 100:1, a wavelength of $532.1 \mathrm{~nm}$, and a $1024 \times 256$ element CCD camera. The signal collected was transmitted via a fiber optic cable into a spectrometer with a $600 \mathrm{~g} / \mathrm{mm}$ grating. The Raman spectra were collected by manually placing the probe tip near the desired point of the sample on a silicon wafer.

\section{Results and discussion}

3.1. The Salt. $n \mathrm{H}_{2} \mathrm{O}-\mathrm{C}_{12} E_{10}$ LLC mesophases and effect of deliquescence of the salts on the stability of LLC mesophases

The salt $\cdot \mathrm{nH}_{2} \mathrm{O}-\mathrm{C}_{12} \mathrm{EO}_{10}$ mesophases covered in this study include some of the $\mathrm{Li}(\mathrm{I}), \mathrm{Na}(\mathrm{I}), \mathrm{K}(\mathrm{I}), \mathrm{Ca}(\mathrm{II})$ and $\mathrm{Mg}(\mathrm{II})$ of $\mathrm{NO}_{3}^{-}, \mathrm{Cl}^{-}$, $\mathrm{Br}^{-}, \mathrm{I}^{-}, \mathrm{SCN}^{-}$and $\mathrm{ClO}_{4}^{-}$anions. Among all of these salts the $\mathrm{Li}(\mathrm{I})$ and $\mathrm{Ca}(\mathrm{II})$ salts exhibit more ordered and stable LLC mesophases. Homogeneous $5 \mathrm{ml}$ aqueous solutions of various salts were prepared at salt/surfactant mole ratios of 1.0, 2.0, 3.0, 4.0 and 5.0. The solutions were then drop casted on glass slides, where the excess water was allowed to evaporate under open atmosphere at RT and 25-30 \%RH. In addition, the samples were also spin coated on glass slides at $1000 \mathrm{rpm}$ from the $5 \mathrm{ml}$ solutions. The spin coated samples were monitored using POM at $25^{\circ} \mathrm{C}$ and 25 \%RH. For samples which are stable and show no sign of salt crystallization, the XRD patterns were collected at small angles to determine whether the samples are ordered or not.

The lithium salts $-\mathrm{C}_{12} \mathrm{E}_{10}$ systems were investigated in details using both XRD and POM techniques. The XRD patterns display 2 or 3 diffraction lines at small angles, see Figs. 1 and S1, characteristic for the LLC mesophases. The diffraction lines between 1.0 and $2.0^{\circ}$ are very close to each other, with a d-spacing ratio of 1.03 , where d-spacings increases from 47 to $64 \AA$ with an increasing lithium salt $/ C_{12} E_{10}$ mole ratio. The third diffraction line is found at a multiple of the first diffraction line and does not provide any additional information. Three diffraction lines can be indexed to a rectangular columnar phase with $\mathbf{a}$ and $\mathbf{b}$ parameters very close to each other. However the second diffraction line may also arise from an inhomogenity along the sample thickness. Since the samples are under open atmosphere, the water concentration along the vertical direction of the sample may vary. The top most layers may include lower water content and therefore diffract at a higher angle. Therefore, the mesophases can still be 2D hexagonal (Columnar; $\mathbf{H}_{\mathbf{1}}$ ). Because of the difficulties in characterization of the mesostructures directly from the XRD data, the POM images 

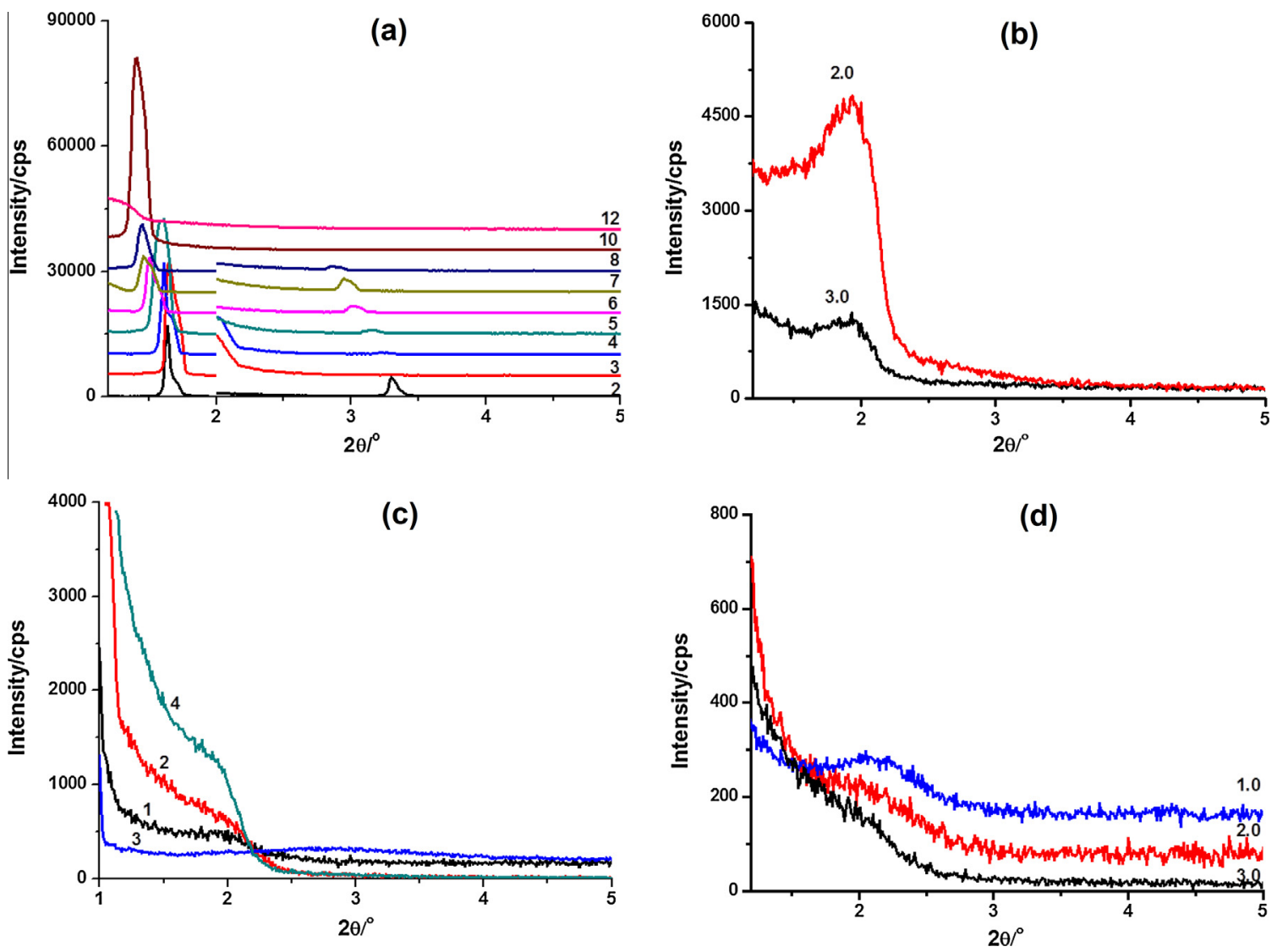

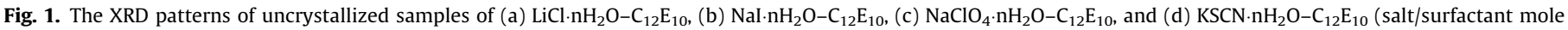
ratios are given on the patterns).

were also recorded to assign the hexagonal to isotropic phase transitions. The hexagonal phases exhibit a fan texture, which are typical for the $\mathbf{H}_{\mathbf{1}}$ phases in these system [8-10,23]. The isotropic phases give a dark image under the POM (while diffracting at low angles) and theoretically should be a $\mathbf{I}_{\mathbf{1}}$ phase (micelle cubic), since $\mathbf{H}_{\mathbf{1}}$ phase is usually transforms to a $\mathbf{I}_{\mathbf{1}}$ phase at higher solvent concentrations $[10,11]$

Among the samples investigated in this work, the stable LLC samples were obtained from the following salts: $\mathrm{LiCl}, \mathrm{LiNO}_{3}, \mathrm{LiBr}$, LiI, $\mathrm{CaCl}_{2}, \mathrm{CaNO}_{3}$ and $\mathrm{MgCl}_{2}$. However, the $\mathrm{CaCl}_{2} \cdot \mathrm{nH}_{2} \mathrm{O}-\mathrm{C}_{12} \mathrm{E}_{10}$ and LiI. $\mathrm{nH}_{2} \mathrm{O}-\mathrm{C}_{12} \mathrm{E}_{10}$ and $\mathrm{MgCl}_{2} \cdot \mathrm{nH}_{2} \mathrm{O}-\mathrm{C}_{12} \mathrm{E}_{10}$ samples exhibit a mesocrystallization upon aging [23], see Fig. S2. Note however that during mesocrystallization salt species are not leached out. Here, the mesocrystallization relates to a semi-crystalline phase in which a collective complexation of salt-water-surfactant species forms a solid-like phase that have larger unit cell parameters compared to the initial LLC phase [23]. The small angle diffraction lines of the mesophase shifts to lower angles with meso-crystallization and many new wide angle diffraction lines appear. The FTIR spectra of the mesocrystals display relatively sharper peaks due to crystalline nature of the new crystals with sharp and intense water peaks at around $3200-3600 \mathrm{~cm}^{-1}$ region (Fig. S2), indicating that the water molecules are still part of the meso-crystals [23].

Among the other salts, the $\mathrm{Na}(\mathrm{I})$ salts, except $\mathrm{NaI}$ and $\mathrm{NaClO}_{4}$ $\mathrm{K}(\mathrm{I})$ salts, except $\mathrm{KSCN}$, and $\mathrm{Mg}(\mathrm{II})$ salts, except $\mathrm{MgCl}_{2}$ are unstable and crystallize rapidly upon spin coating. The $\mathrm{NaI} \cdot \mathrm{nH}_{2} \mathrm{O}-\mathrm{C}_{12} \mathrm{E}_{10}$ system is stable at a $3 \mathrm{NaI} / \mathrm{C}_{12} \mathrm{E}_{10}$ mole ratio; however the XRD patterns show very weak and broad diffraction lines at small angles, indicating a disordered mesophase as compared to the $\mathrm{Li}(\mathrm{I})$ and $\mathrm{Ca}$ (II) systems, see Fig. $1 \mathrm{~b}$. The $\mathrm{NaI} \cdot \mathrm{nH}_{2} \mathrm{O}-\mathrm{C}_{12} \mathrm{E}_{10}$ samples are unstable above a 3 salt/surfactant mole ratio and excess salt is leached out. Note also that the $\mathrm{I}^{-}$ion is a chaotropic anion (chaotropic anions are known as salting-in ions or structure breakers) [12$20]$, and enhances the diffusion of water in the hydrophilic (ethylene oxide)-hydrophobic (alkyl group) interface of the mesophase and may destroy the meso-order. To overcome this problem, we also tested $\mathrm{C}_{18} \mathrm{E}_{10}$ (extra $6-\mathrm{CH}_{2}$ - units in the alkyl tail to increase the strength of the hydrophobic core in the mesophase) as a surfactant to form ordered and stable LLC mesophases of the $\mathrm{NaI} \cdot \mathrm{nH}_{2} \mathrm{O}-\mathrm{C}_{18} \mathrm{E}_{10}$ system, up to a NaI/ $\mathrm{C}_{18} \mathrm{E}_{10}$ mole ratio of 7 . These samples are also birefringent and display fan texture (characteristic for the hexagonal phase) between the crossed polarizers under POM and have sharp diffraction line(s) at small angles in the XRD patterns. The $\mathrm{NaClO}_{4} \cdot \mathrm{nH}_{2} \mathrm{O}-\mathrm{C}_{12} \mathrm{E}_{10}$ and $\mathrm{KSCN} \cdot \mathrm{nH}_{2} \mathrm{O}-\mathrm{C}_{12} \mathrm{E}_{10}$ systems are stable at a 2 salt/surfactant mole ratio but again there is little or no mesostructured order, see Fig. 1(c and d). The results of these observations are summarized in Table 2 , in which the salts were categorized as Type I(Blue), Type II(Green), and Type III(Red). Type

Table 2

The hydrated salt- $\mathrm{C}_{12} \mathrm{E}_{10}$ LLC mesophases: (I) stable LLC phase, (II) no salt crystallization at low salt concentrations and disordered isotropic, and (III) salt crystallizes out. The symbols indicate: $(-)$ not-studied, $*$ mesocrystallization over time, and LS low solubility.

\begin{tabular}{lllllllll}
\hline & \multicolumn{7}{c}{ Anions } & \multicolumn{7}{c}{ Cations } & $\mathrm{OAc}^{-}$ & $\mathrm{Cl}^{-}$ & $\mathrm{Br}^{-}$ & $\mathrm{I}^{-}$ & $\mathrm{NO}_{3}^{-}$ & $\mathrm{ClO}_{4}^{-}$ & $\mathrm{SCN}^{-}$ & $\mathrm{F}^{-}$ \\
\hline $\mathrm{Li}^{+}$ & - & I & I & I $^{*}$ & I & III & - & LS \\
$\mathrm{Na}^{+}$ & III & III & III & II & III & II & III & - \\
$\mathrm{K}^{+}$ & - & III & - & III & III & LS & II & - \\
$\mathrm{Ca}^{2+}$ & - & $\mathrm{II}^{*}$ & - & - & I & - & - & - \\
$\mathrm{Mg}^{2+}$ & - & $\mathrm{I}^{*}$ & - & - & III & - & - & - \\
\hline
\end{tabular}


I salts are usually stable over a broad range of salt concentrations and exhibit LLC mesophases. Type II salts are stable at low salt concentrations and exhibit little or no mesostructured order. Type III salts rapidly leaches out salt crystals from the salt-water-surfactant films.

These trends among different salts can be explained by taking into account the hygroscopic behavior of the salts. The surfactant molecules are unable to store a large amount of water to maintain the mesophases without the salts. Most hygroscopic salts can exhibit deliquescence where the salt crystals are dissolved spontaneously by the absorbed water molecules from the air. Table 1 gives a list of \%DRH of some salts. Among all monovalent salts, $\mathrm{Li}(\mathrm{I})$ salts have very low \%DRH values as compared to $\mathrm{Na}(\mathrm{I})$ and $\mathrm{K}(\mathrm{I})$ salts. It is seen in the table that Type I salts such as $\mathrm{LiCl}, \mathrm{LiBr}$, LiI and $\mathrm{LiNO}_{3}$ have \%DRH levels lower than 20\% [25-29] which is also lower than our experimental conditions, 20-25\%. This may explain the higher stability of the $\mathrm{Li}(\mathrm{I})$ containing LLC mesophases. Among the Type II salts, the \%DRH values of the $\mathrm{NaI}$ and $\mathrm{NaClO}_{4}$ salts are $38.17 \%$ [25] and 43-46\% [27,28], respectively. It is also seen that all Type III salts have a \%DRH higher than 50\% [25-29]. The high \%DRH may explain the instant crystallization of the salt species in the Type III salt systems. On the other hand Type II salt systems are stable at low salt concentrations (2-3 salt/surfactant mole ratio) with little or no mesostructured order.

The divalent metal salts should be considered separately because the $\mathrm{M}(\mathrm{II}) \cdots \mathrm{H}_{2} \mathrm{O} \cdots \mathrm{OCH}_{2} \mathrm{CH}_{2}$ - chain interactions are much stronger as compared to the monovalent cations. For instance, the \%DRH values of $\mathrm{Mg}\left(\mathrm{NO}_{3}\right)_{2}$ and $\mathrm{Ca}\left(\mathrm{NO}_{3}\right)_{2}$ are very similar $52 \%$ and $51 \%$, respectively [25], but the stability of their LLC mesophases are very different. The samples of $\mathrm{Mg}\left(\mathrm{NO}_{3}\right)_{2} \cdot \mathrm{nH}_{2} \mathrm{O}-\mathrm{C}_{12} \mathrm{E}_{10}$ mesophases rapidly crystallize when spin coated, however the $\mathrm{Ca}\left(\mathrm{NO}_{3}\right)_{2} \cdot \mathrm{nH}_{2} \mathrm{O}-\mathrm{C}_{12} \mathrm{E}_{10}$ samples are stable indefinitely. Therefore the $\mathrm{Ca}(\mathrm{II}) \cdots \mathrm{H}_{2} \mathrm{O} \cdots \mathrm{OCH}_{2} \mathrm{CH}_{2}$ - chain interactions must be significant in the $\mathrm{Ca}\left(\mathrm{NO}_{3}\right)_{2} \cdot \mathrm{nH}_{2} \mathrm{O}-\mathrm{C}_{12} \mathrm{E}_{10}$ samples. The chloride salts of both $\mathrm{Ca}$ (II) and $\mathrm{Mg}(\mathrm{II})$ have lower \%DRH values as compared to nitrate salts, 33\% and 31\% respectively [25], and form LLC mesophases, however they undergo mesocrystallization [23]. The divalent cation has a stronger interaction with the hydrophilic domains of the mesophase and the salt-surfactant interactions contribute more to the phase behavior as compared to the monovalent cations. Additional factors may also contribute to the mesophase behavior such as: the effect of the anion, the salt concentration, temperature, pressure, relative humidity, hydrophobic-lipophilic balance (HLB) of the surfactant and also the soft confinement effect [11]. For instance, a more hydrophobic surfactant induces LLC mesophase formation in the presence of $\mathrm{LiClO}_{4}$ at low salt concentrations. It is possible that, Type II salts may exhibit LLC mesophases at higher humidity levels, and/or by increasing the hydrophobic regions of the mesophase by increasing the alkyl chain length (such as changing the surfactant from $\mathrm{C}_{12} \mathrm{E}_{10}$ to $\mathrm{C}_{18} \mathrm{E}_{10}$ ). Comparative studies are required to elucidate the nature of the selfassembly.

\subsection{Stability and thermal behavior of the $\mathrm{LiX} \cdot \mathrm{nH}_{2} \mathrm{O}-\mathrm{C}_{12} \mathrm{E}_{10} \mathrm{LLC}$ mesophases}

We have investigated the stable mesophases in detail using PXRD, POM, FTIR and Raman and thermal techniques. Figs. 1(a) and $\mathrm{S} 1$ show the XRD patterns of the $\mathrm{LiCl} \cdot \mathrm{nH}_{2} \mathrm{O}-\mathrm{C}_{12} \mathrm{E}_{10}, \mathrm{LiNO}_{3} \cdot \mathrm{nH}_{2}$ $\mathrm{O}-\mathrm{C}_{12} \mathrm{E}_{10}$, LiBr$\cdot \mathrm{nH}_{2} \mathrm{O}-\mathrm{C}_{12} \mathrm{E}_{10}$, LiI. $\mathrm{nH}_{2} \mathrm{O}-\mathrm{C}_{12} \mathrm{E}_{10}$ and $\mathrm{LiClO}_{4} \cdot \mathrm{nH}_{2} \mathrm{O}-$ $\mathrm{C}_{12} \mathrm{E}_{10}$ systems at different salt $/ \mathrm{C}_{12} \mathrm{E}_{10}$ mole ratios, respectively. The general trend is that the diffraction line shifts to smaller angles with an increasing salt concentration in all of the salt systems, corresponding to a d-spacing change of about $15 \%$. This means that the hydrophilic domains expand with an increasing salt concentration in the LLC mesophases. The $\mathrm{LiCl} \cdot \mathrm{nH}_{2} \mathrm{O}-\mathrm{C}_{12} \mathrm{E}_{10}$ and $\mathrm{LiBr} \cdot \mathrm{nH}_{2} \mathrm{O}-$
$\mathrm{C}_{12} \mathrm{E}_{10}$ systems form LLC mesophases over a broad range of salt/surfactant mole ratios (2-12, corresponds to $22-62 \mathrm{w} / \mathrm{w} \% \mathrm{LiBr}$ ). The lattice parameters are changed from 62 to $72 \AA$ from $\mathrm{Li}(\mathrm{I}) / \mathrm{C}_{12} \mathrm{E}_{10}$ mole ratio of 2-10 in the $\mathrm{LiCl}$ system, keeping the hexagonal phase in all compositions. However, the $\mathrm{LiBr}$ and Lil systems undergo a phase change from hexagonal to cubic at around 6 and $3 \mathrm{Li}(\mathrm{I}) / \mathrm{C}_{12} \mathrm{E}_{10}$ mole ratio (see Table 3 for structural details). The $\mathrm{LiCl} \cdot \mathrm{nH}_{2} \mathrm{O}-\mathrm{C}_{12} \mathrm{E}_{10}$, $\mathrm{LiBr} \cdot \mathrm{nH}_{2} \mathrm{O}-\mathrm{C}_{12} \mathrm{E}_{10}$ and LiI. $\mathrm{nH}_{2} \mathrm{O}-\mathrm{C}_{12} \mathrm{E}_{10}$ samples show no sign of salt crystallization under the specified experimental conditions but become disordered over a salt/surfactant mole ratio of 10-12.

Furthermore, the $\mathrm{LiNO}_{3} \cdot \mathrm{nH}_{2} \mathrm{O}-\mathrm{C}_{12} \mathrm{E}_{10}$ system leaches out some the $\mathrm{LiNO}_{3}$ crystals above a $\mathrm{LiNO}_{3} / \mathrm{C}_{12} \mathrm{E}_{10}$ mole ratio of 6 . The samples are stable over time. Fig. 2 shows the XRD patterns followed for 1 week. There are small changes in the pattern over time but in general the samples are stable to aging under ambient conditions, see Fig. 2. On the other hand, the $\mathrm{LiClO}_{4} \cdot \mathrm{nH}_{2} \mathrm{O}-\mathrm{C}_{12} \mathrm{E}_{10}$ system does not form a stable LLC phase even at a salt/surfactant mole ratio of 1 and leach out $\mathrm{LiClO}_{4}$ crystals, see Fig. 3(a). However the $\mathrm{LiClO}_{4} \cdot \mathrm{nH}_{2} \mathrm{O}-\mathrm{C}_{18} \mathrm{E}_{10}$ samples in which the surfactant molecule has extra $6-\mathrm{CH}_{2}$ - units in the tail (hydrophobic core region) exhibit stable LLC mesophases up to a salt/surfactant mole ratio of 3 . Table 3 summarizes our assignments of the mesophases based on the XRD and POM data, obtained at RT and 23-25 \%RH from all the salts and compositions together with the lattice parameters. It is seen that for different anions the cubic phase transition follows a Hofmeister series.

The LiX. $\mathrm{nH}_{2} \mathrm{O}-\mathrm{C}_{12} \mathrm{E}_{10}$ samples (where $\mathrm{X}$ is $\mathrm{NO}_{3}^{-}, \mathrm{Cl}^{-}, \mathrm{Br}^{-}, \mathrm{I}^{-}$, and $\mathrm{ClO}_{4}^{-}$) were further investigated to elucidate the effects of the anions on the stability, phase behavior of the mesophases under ambient conditions, and the thermal behaviors. Fig. 4 shows the Raman spectra of the $\mathrm{LiNO}_{3} \cdot \mathrm{nH}_{2} \mathrm{O}-\mathrm{C}_{12} \mathrm{E}_{10}$ sample (where $\mathrm{LiNO}_{3}$ / $\mathrm{C}_{12} \mathrm{E}_{10}$ mole ratio is 3 ) at three different \% $\mathrm{RH}$ levels. The intensity of the $\mathrm{v}-\mathrm{OH}$ stretching band at around $3000-3500 \mathrm{~cm}^{-1}$ indicates that the amount of water in the sample increases with increasing \% RH in the atmosphere. The water content of the spin coated samples was also evaluated using FT-IR spectroscopy. Fig. S3(a) shows the FT-IR spectra of $3 \mathrm{LiNO}_{3} \cdot \mathrm{nH}_{2} \mathrm{O}-1 \mathrm{C}_{12} \mathrm{E}_{10}$ (under $25 \% \mathrm{RH}$ at RT), $35 \mathrm{H}_{2} \mathrm{O}-1 \mathrm{C}_{12} \mathrm{E}_{10}$ and $3 \mathrm{LiNO}_{3} \cdot 15 \mathrm{H}_{2} \mathrm{O}-1 \mathrm{C}_{12} \mathrm{E}_{10}$ samples (numbers indicate the mole ratio of each species; see supporting information for the details). The spectra were normalized with respect to the $v$ $\mathrm{CH}$ stretchings peaks of the surfactant. The FT-IR spectra of the $35 \mathrm{H}_{2} \mathrm{O}-\mathrm{C}_{12} \mathrm{E}_{10}$ and $3 \mathrm{LiNO}_{3} \cdot 15 \mathrm{H}_{2} \mathrm{O}-\mathrm{C}_{12} \mathrm{E}_{10}$ samples were collected by sandwiching them between $\mathrm{Si}$ wafers to avoid water evaporation. The $v-O H$ stretching of the water band $3000-3700 \mathrm{~cm}^{-1}$ gives quantitative information about the water content of the samples. It is seen in Fig. $\mathrm{S} 3$ that the amount of water in the sample, $3 \mathrm{LiX} \cdot \mathrm{nH}_{2}$ $\mathrm{O}-\mathrm{C}_{12} \mathrm{E}_{10}$ (where $\mathrm{X}$ is $\mathrm{Cl}^{-}$and $\mathrm{NO}_{3}^{-}$) and is lower than 15.0, which means the water/salt mole ratio is below 5.0. Overall these experiments indicate that the spin coated samples which were left open to the surrounding atmosphere is highly concentrated in terms of salt/water mole ratio and is stable under the given temperature and \%RH level.

The isotropization temperatures (ITs) were also measured from the lithium series to show the stability of the LLC mesophases (see Table 4). Notice that the $\mathrm{LiBr} \cdot \mathrm{nH}_{2} \mathrm{O}-\mathrm{C}_{12} \mathrm{E}_{10}$ samples do not melt up to $136{ }^{\circ} \mathrm{C}$ in a $5 \mathrm{LiBr} / \mathrm{C}_{12} \mathrm{E}_{10}$ mole ratio. This is the highest IT that has been recorded from a LLC mesophase. There is a correlation between the highest ITs and the salt concentration in each saltsurfactant system. It is likely that each salt species interacts with the surfactant molecules at a different strength and needs to be explored further.

\subsection{The Hofmeister effect on the LiX.nH $\mathrm{H}_{2} \mathrm{O}-\mathrm{C}_{12} E_{10}$ LLC mesophases}

As mentioned earlier, the salt-surfactant LLC mesophases undergo an hexagonal $\left(\mathrm{H}_{1}\right)$ to cubic $\left(\mathrm{I}_{1}\right)$ phase transition following 
Table 3

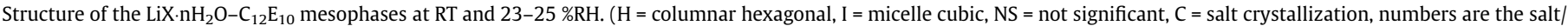
surfactant mole ratios and $*$ meso-crystallization upon aging and the numbers in the paranthasis are lattice parameters in $\AA$ ).

\begin{tabular}{|c|c|c|c|c|c|c|c|c|c|}
\hline \multirow[b]{2}{*}{ Salt } & \multicolumn{9}{|c|}{ Salt/surfactant mole ratio } \\
\hline & 2 & 3 & 4 & 5 & 6 & 7 & 8 & 10 & 12 \\
\hline $\mathrm{LiNO}_{3}$ & NS & $\begin{array}{l}\mathrm{H} \\
(58)\end{array}$ & $\begin{array}{l}\mathrm{H} \\
(61)\end{array}$ & $\begin{array}{l}\mathrm{H} \\
(62)\end{array}$ & $\begin{array}{l}\mathrm{H} \\
(65)\end{array}$ & $\begin{array}{l}\mathrm{H} \\
(65)\end{array}$ & $\begin{array}{l}\mathrm{H} \\
(67)\end{array}$ & - & - \\
\hline $\mathrm{LiCl}$ & $\begin{array}{l}\mathrm{H} \\
(62)\end{array}$ & $\begin{array}{l}\mathrm{H} \\
(62)\end{array}$ & $\begin{array}{l}\mathrm{H} \\
(63)\end{array}$ & $\begin{array}{l}\mathrm{H} \\
(64)\end{array}$ & $\begin{array}{l}\mathrm{H} \\
(67)\end{array}$ & $\begin{array}{l}\mathrm{H} \\
(70)\end{array}$ & $\begin{array}{l}\mathrm{H} \\
(71)\end{array}$ & $\begin{array}{l}\mathrm{H} \\
(72)\end{array}$ & - \\
\hline $\mathrm{LiBr}$ & $\begin{array}{l}\mathrm{H} \\
(56)\end{array}$ & $\begin{array}{l}\mathrm{H} \\
(57)\end{array}$ & $\begin{array}{l}\mathrm{H} \\
(58)\end{array}$ & $\begin{array}{l}\mathrm{H} \\
(59)\end{array}$ & $\begin{array}{l}\text { I } \\
(118)\end{array}$ & $\begin{array}{l}\text { I } \\
(124)\end{array}$ & $\begin{array}{l}\text { I } \\
(124)\end{array}$ & $\begin{array}{l}\text { I } \\
(130)\end{array}$ & \\
\hline LiI & $\mathrm{H}$ & $\mathrm{H}+\mathrm{I}$ & $\mathrm{I}^{*}$ & $\mathrm{I}^{*}$ & $\mathrm{I}^{*}$ & $\mathrm{I}^{*}$ & $\mathrm{I}^{*}$ & - & - \\
\hline $\mathrm{LiClO}_{4}$ & NS & $\mathrm{C}$ & - & 0 & - & - & - & - & - \\
\hline
\end{tabular}
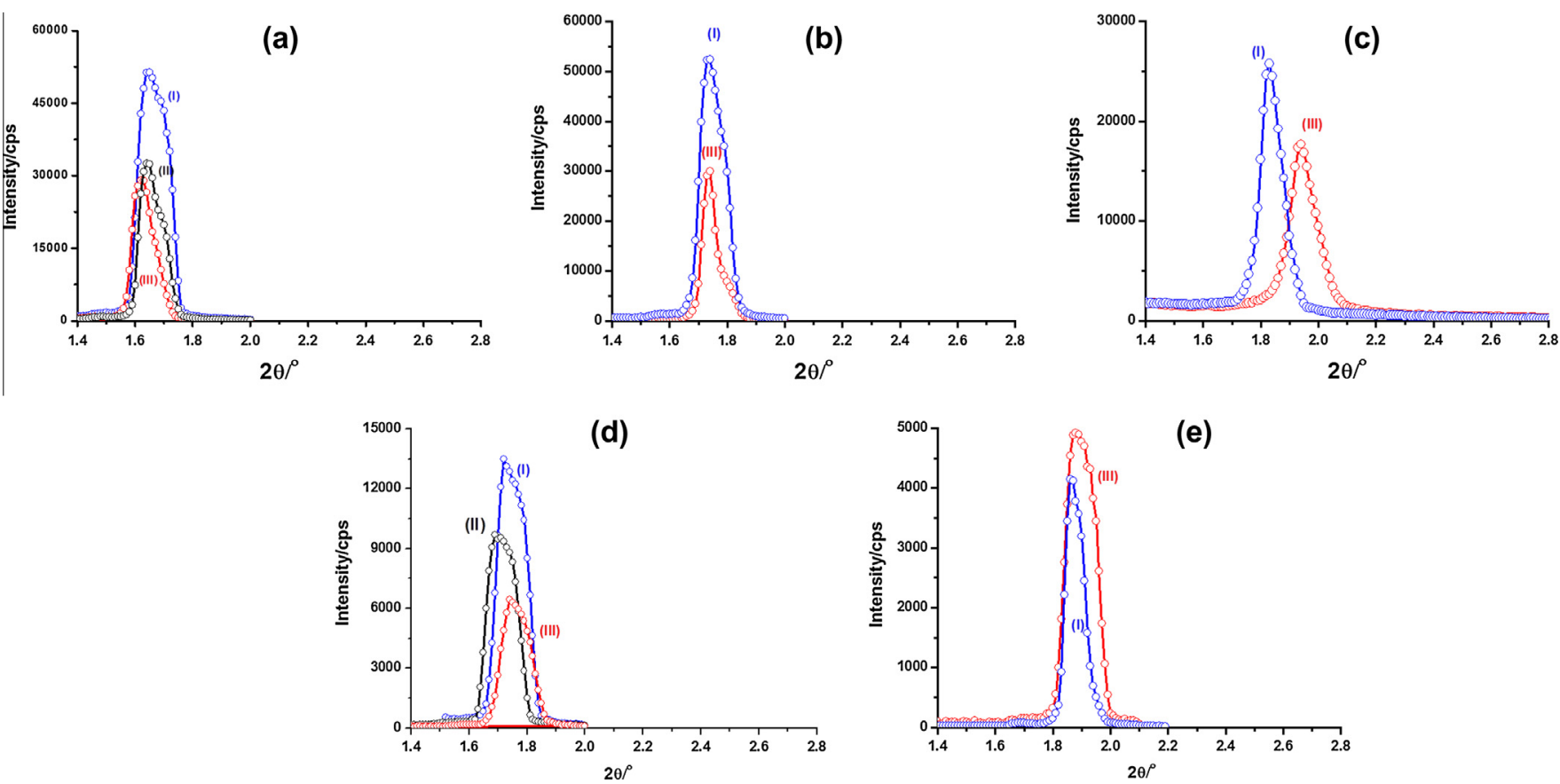

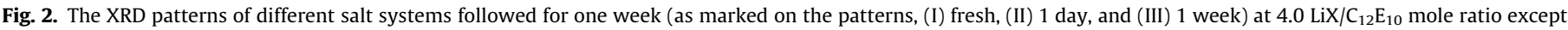
$\mathrm{LiClO}_{4}$ (2.0 salt/surfactant mole ratio) $\mathrm{X}$ is (a) $\mathrm{Cl}^{-}$, (b) $\mathrm{Br}^{-}$, (c) $\mathrm{I}^{-}$, (d) $\mathrm{NO}_{3}^{-}$, and (e) $\mathrm{ClO}_{4}^{-}$. The measurements were done at $23-25{ }^{\circ} \mathrm{C}$ and $21-25 \% \mathrm{RH}^{-}$
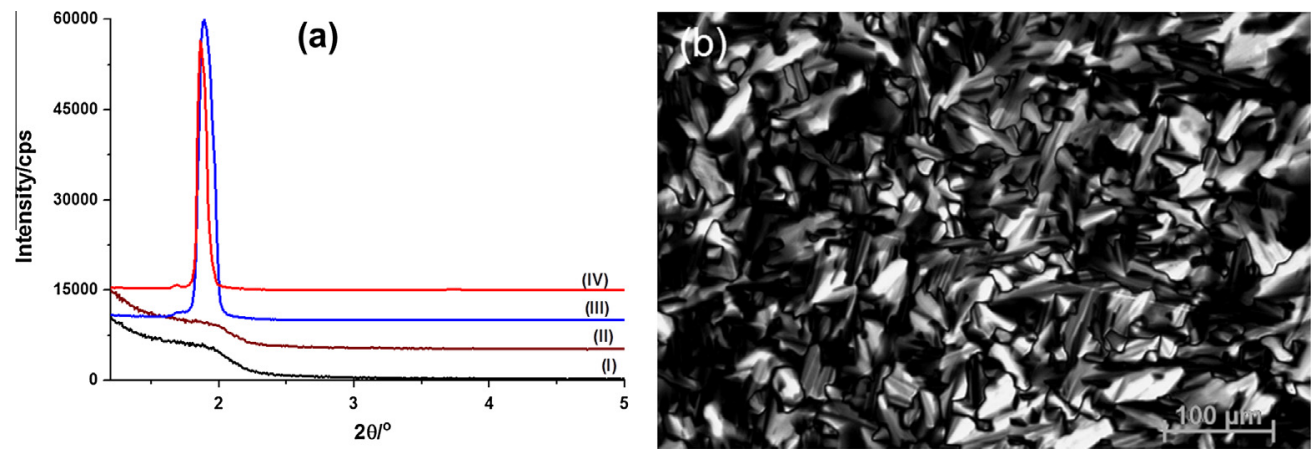

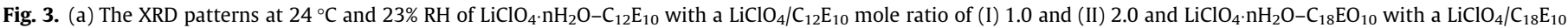
mole ratio of (III) 1.0 and (IV) 2.0. (b) The POM images of the sample with a salt surfactant mole ratio of 2.0 of $\mathrm{LiClO}_{4} \cdot \mathrm{nH}_{2} \mathrm{O}-\mathrm{C}_{18} \mathrm{E}_{10}$.

the Hofmeister series, see Table 3. While there is no $\mathrm{H}_{1}$ to $\mathrm{I}_{1}$ phase transition in the $\mathrm{LiNO}_{3} \cdot \mathrm{nH}_{2} \mathrm{O}-\mathrm{C}_{12} \mathrm{E}_{10}$ and $\mathrm{LiCl} \cdot \mathrm{nH}_{2} \mathrm{O}-\mathrm{C}_{12} \mathrm{E}_{10}$ LLC mesophases, the transition starts around a $4.0 \mathrm{LiBr} / \mathrm{C}_{12} \mathrm{E}_{10}$ mole ratio in the $\mathrm{LiBr} \cdot \mathrm{nH}_{2} \mathrm{O}-\mathrm{C}_{12} \mathrm{E}_{10}$ and a 3.0 mole ratio in the Lil. $\mathrm{nH}_{2-}$ $\mathrm{O}-\mathrm{C}_{12} \mathrm{E}_{10}$ LLC mesophases. It is known that the structure breakers (such as $\mathrm{NO}_{3}^{-}, \mathrm{Br}^{-}, \mathrm{I}^{-}$, and $\mathrm{ClO}_{4}^{-}$) are usually loosely hydrated and can penetrate in the vicinity of the core-shell interface more as compared to the structure makers (such as $\mathrm{Cl}^{-}$) and therefore, these ions tend to increase the interfacial curvature of the hydrophobic-hydrophilic interface of the mesophase [7-20]. From 


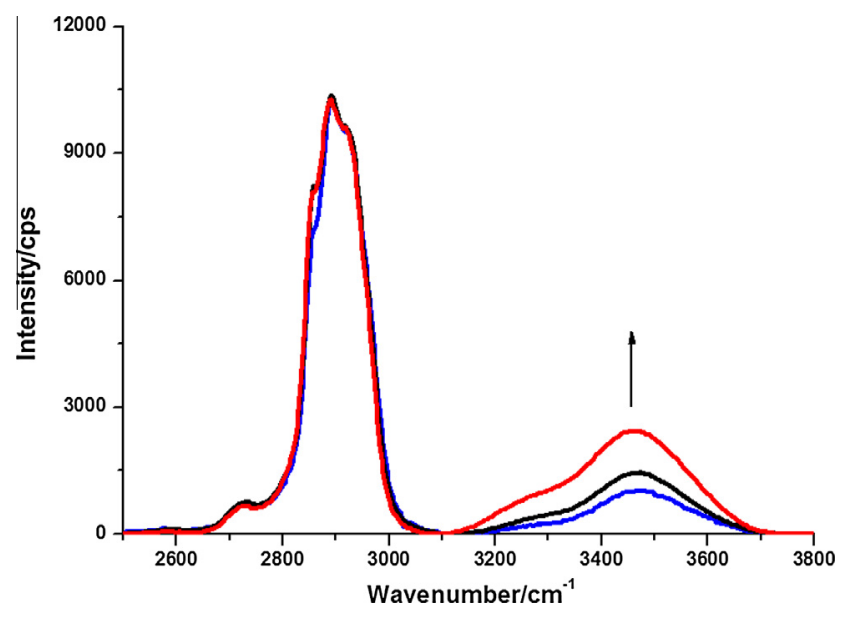

Fig. 4. Raman spectra of $\mathrm{LiNO}_{3} \cdot \mathrm{nH}_{2} \mathrm{O}-\mathrm{C}_{12} \mathrm{E}_{10}\left(\mathrm{LiNO}_{3} / \mathrm{C}_{12} \mathrm{E}_{10}\right.$ mole ratio is 3$)$ under $25 \%, 40 \%$ and $65 \% \mathrm{RH}$ and at RT.

Table 4

Isotropization temperatures (ITs), ${ }^{\circ} \mathrm{C}$, of the lithium salt $-\mathrm{C}_{12} \mathrm{E}_{10}$ systems at various salt/surfactant mole ratios. The table was established using POM and only the hexagonal phase was investigated.

\begin{tabular}{|c|c|c|c|c|c|}
\hline \multirow[b]{2}{*}{ Salt } & \multicolumn{5}{|c|}{ Salt/surfactant ratio } \\
\hline & 2 & 3 & 4 & 5 & 6 \\
\hline $\mathrm{LiCl}$ & - & 36 & 56 & 63 & 69 \\
\hline $\mathrm{LiBr}$ & 40 & 92 & 126 & 136 & - \\
\hline LiI & 74 & 96 & 75 & - & - \\
\hline $\mathrm{LiNO}_{3}$ & - & 58 & 67 & 73 & 78 \\
\hline
\end{tabular}

another point of view the structure breaker ions can also increase the hydration of the ethylene oxide chains, which again results in an increase in the cross sectional area of surfactant molecules and so the interfacial curvature [7-20]. When the concentration of a structure breaker ion is increased, the repulsive forces between the hydrophilic chains increase and eventually a phase transition to a phase with higher curvature is observed. In this study, the $\mathrm{H}_{1}$ to $\mathrm{I}_{1}$ phase transition is observed with the following order of ions $\mathrm{I}^{-}>\mathrm{Br}^{-}>\mathrm{NO}_{3}^{-} \sim \mathrm{Cl}^{-}$; which corresponds with the Hofmeister series [21]. In the $\mathrm{LiX} \cdot \mathrm{nH}_{2} \mathrm{O}-\mathrm{C}_{12} \mathrm{E}_{10}$ systems, the Hofmeister series is followed except in the $\mathrm{LiClO}_{4} \cdot \mathrm{nH}_{2} \mathrm{O}-\mathrm{C}_{12} \mathrm{E}_{10}$ system. There may be two limitations of $\mathrm{LiClO}_{4}$ salt (it is a Type III salt, see Table 2): (i) $\mathrm{LiClO}_{4}$ salt is not as hygroscopic as the other salts, that is, the salt-water interactions are weaker and (ii) it is also possible that the $\mathrm{ClO}_{4}^{-}$ion with a hydration sphere is disrupting the mesophase by making the surfactant molecules too hydrophilic - by breaking the water structure and hydrating the ethylene oxide chain more. We therefore used a more hydrophobic surfactant, $\mathrm{C}_{18} \mathrm{E}_{10}$, in order to adjust the hydrophilic-lipophilic balance in the presence of $\mathrm{ClO}_{4}^{-}$ ion. Expectedly, the $\mathrm{C}_{18} \mathrm{E}_{10}$ surfactant exhibits a stable $\mathrm{H}_{1}$ mesophase with $\mathrm{LiClO}_{4}$ up to 3 salt/surfactant mole ratio, see Fig. 4 for the XRD patterns and POM image. However, the samples crystallize at a $\mathrm{LiClO}_{4} / \mathrm{C}_{18} \mathrm{E}_{10}$ mole ratio of 3 and above over time.

\subsection{Salt-water-surfactant interactions, IR and Raman spectroscopic studies}

The FTIR spectra of the LiX $\cdot \mathrm{nH}_{2} \mathrm{O}-\mathrm{C}_{12} \mathrm{E}_{10}$ mesophases were also collected (at $27{ }^{\circ} \mathrm{C}$ and $22 \% \mathrm{RH}$ ) at different $\mathrm{LiX} / \mathrm{C}_{12} \mathrm{E}_{10}$ mole ratios to investigate the effect of anions on the phase behaviors, at a molecular level, see Figs. 5, S4, and S5. An increase in the mole ratio of salt species is accompanied by an increase in the intensity of the

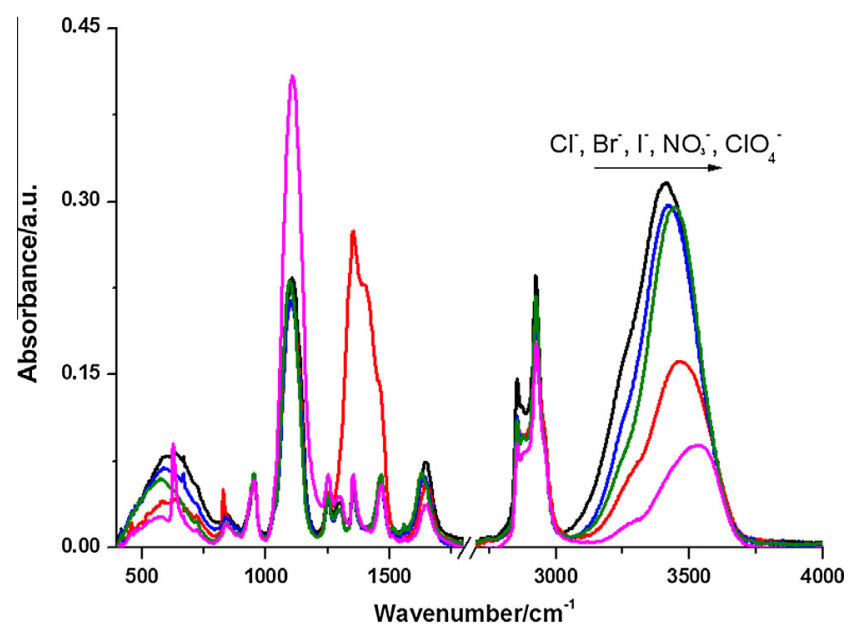

Fig. 5. FTIR spectra of LiX. $\mathrm{nH}_{2} \mathrm{O}-\mathrm{C}_{12} \mathrm{E}_{10}$ with a $\mathrm{LX} / \mathrm{C}_{12} \mathrm{E}_{10}$ mole ratio of 3.0 and $\mathrm{X}$ is (a) $\mathrm{Cl}^{-}$(black), (b) $\mathrm{Br}^{-}$(blue), (c) $\mathrm{I}^{-}$(olive), (d) $\mathrm{NO}_{3}^{-}$(red), and (e) $\mathrm{ClO}_{4}^{-}$(pink). (For interpretation of the references to color in this figure legend, the reader is referred to the web version of this article.)

v-OH band of water at around $3100-3700 \mathrm{~cm}^{-1}$, Figs. S4 and S5. This means that - the amount of water-kept in the mesophase, is directly related to the salt concentration (see supporting information section for the details). When the intensity of the $\mathrm{v}$-OH band is considered, it is shown that the $\mathrm{LiClO}_{4}$ system cannot hold much water and $\mathrm{NO}_{3}^{-}$system also have lower water content as compared to halide systems, compare Fig. 5 . The halide systems contain more or less the same amount of water and the $\mathrm{v}-\mathrm{OH}$ band exhibits a similar spectral peak shape that can also be found in concentrated electrolyte solutions, Fig. S6(A) [32,33]. However, increasing the salt mole ratio does not affect the maxima of the water stretching peak. Indeed, the water band can be fitted to three different peaks, see Fig. S6(B). The low energy contribution of the $\mathrm{v}-\mathrm{OH}$ band is related to the hydrogen bonded (bulk water) or coordinated water molecules and the high energy ones are related to "free" water molecules [32,33]. In aqueous solutions of structure breaker ions, the intensity of the low energy signals decreases due to the disruption of the hydrogen bonding network of the bulk water. Similarly, in the $\mathrm{LiX} \cdot \mathrm{nH}_{2} \mathrm{O}-\mathrm{C}_{12} \mathrm{E}_{10}$ systems, it is seen that the low energy portion of the $\mathrm{v}-\mathrm{OH}$ band disappears and the band width gets sharper.

The $v$-CO stretching frequency (around $1100 \mathrm{~cm}^{-1}$ ) is also sensitive to the hydrated metal ion-surfactant interactions. This band is usually red-shifted in the salt $\cdot \mathrm{nH}_{2} \mathrm{O}-\mathrm{C}_{12} \mathrm{E}_{10}$ samples as compared to the pure $\mathrm{C}_{12} \mathrm{E}_{10}$ and $\mathrm{H}_{2} \mathrm{O}-\mathrm{C}_{12} \mathrm{E}_{10}$ samples, indicating a stronger surfactant-solvent interactions (hydrogen bonding between the hydration or coordinated water sphere with ethylene oxide groups) and also some degree of direct metal ion-ethylene oxide interactions are stronger in the salt-surfactant mesophases. In addition the magnitude of the red-shift in the $\mathrm{v}$-CO stretching increases with the charge on the metal ion. The $v$-CO stretching band of the molten surfactant is around $1200 \mathrm{~cm}^{-1}$ and shifts to $1103 \mathrm{~cm}^{-1}$ in the presence of water $\left(1 / 1 \mathrm{w} / \mathrm{w}\right.$ ratio of $\mathrm{H}_{2} \mathrm{O}$ / $\mathrm{C}_{12} \mathrm{E}_{10}$ ) and to $1085 \mathrm{~cm}^{-1}$ in the divalent metal salt systems such as $\mathrm{Zn}^{2+}[11]$. However, the position of this band does not change significantly in the presence of monovalent salts and it is observed at around $1104,1100,1098$, and $1095 \mathrm{~cm}^{-1}$ in the $\mathrm{LiX} \cdot \mathrm{nH}_{2} \mathrm{O}$ $\mathrm{C}_{12} \mathrm{E}_{10}$, where $\mathrm{X}$ is $\mathrm{Cl}^{-}, \mathrm{NO}_{3}^{-}, \mathrm{Br}^{-}$, and $\mathrm{I}^{-}$, respectively, Fig. 5. This shows that the lithium ions interact with the ethylene oxide units mostly through the hydrated water molecules. While the differences in the $v$-CO stretching between different anions is not so significant, the trend, in the $v-\mathrm{CO}$, follows the Hofmeister series for different anions, $\mathrm{Cl}^{-}>\mathrm{NO}_{3}^{-}>\mathrm{Br}^{-}>\mathrm{I}^{-}$. This trend can be explained by increasing the hydration of the ethylene oxide chains 
with the addition of more chaotropic (structure breaker) ions. Basically, the chaotropic ions, such as $\mathrm{I}^{-}$, break the bulk water structure and penetrate with a hydration sphere more to the vicinity of the core-shell (hydrophobic-hydrophilic) interface of the surfactant assembly. These effects are also visible in the phase transitions. The ions that enhance the solvent-surfactant interactions make the surfactant more hydrophilic and enforce a $\mathbf{H}_{\mathbf{1}}$ to $\mathbf{I}_{\mathbf{1}}$ transition (see Table 3), where the cubic phase can accommodate more solvent.

\section{Conclusions}

A correlation between the \%DRH value of the salts and the formation/stability of the salt $\cdot \mathrm{nH}_{2} \mathrm{O}-\mathrm{C}_{i} \mathrm{E}_{j}$ LLC mesophases $[8,10]$ has been found. Among a number of different salts, $\mathrm{Li}(\mathrm{I}), \mathrm{Ca}(\mathrm{II})$ and $\mathrm{Mg}$ (II) salts exhibited stable LLC mesophases (Type I salts) and have the lowest \%DRH values.[25-29] However some of the Type I salts form mesO-Crystals with $\mathrm{C}_{12} \mathrm{E}_{10}$ under ambient condition upon aging [23]. Salts that have intermediate \%DRH values such as $\mathrm{NaClO}_{4}$, NaI and KSCN formed stable mesophases at low salt concentrations with a little or no mesostructured order (Type II salts). However the meso-order, the stability, and the amount of salt in the mesophases of Type II salts can be enhanced by increasing the alkyl chain length of the surfactant. By increasing the chain length of the surfactant by $6 \mathrm{CH}_{2}$ units made some of the Type Il salts act like Type I. The salts that have high \%DRH values were either insoluble or rapidly leached out after spin coating from homogeneous solutions containing salt, surfactant and water. It is likely that many other salts with low \%DRH levels can also form LLC mesophases with non-ionic amphiphiles at high salt concentrations. The phase transitions among different $\mathrm{Li}(\mathrm{I})$ salts follow the Hofmeister series. FT-IR studies indicate that the ions interact with the surfactants mostly through hydration waters. The systems are highly concentrated in terms of water and salt and the water content of the samples depends on the \% RH and salt concentration. The findings amplify the understanding of the salt-surfactant LLC phases and highlight the origin and stability of these types of LLC phases. Furthermore, the salt $\mathrm{nH}_{2} \mathrm{O}-\mathrm{C}_{i} \mathrm{E}_{j}$ mesophases should be regarded as an example system for the development of gel-electrolytes and to expand the solvent type toward new applications of the LLC phases $[1-8,10]$. We believe that the hygroscopic salts are also potentially important in other self-assembling soft materials [23]. Further investigations are required to form their phase diagrams, to determine low and high temperature behaviors of these new LLC phases. The new mesophases can be used as phase changing materials, gel-electrolytes, media for many chemical reactions, and for the synthesis of new advanced functional mesoporous materials and will contribute for the advancement of the colloids and interface science.

\section{Acknowledgments}

Authors thanks to TÜBITAK under the project numbers $112 \mathrm{~T} 407$ for financial support. Ö.D. is a member of the Science Academy, Istanbul, Turkey.

\section{Appendix A. Supplementary material}

Supplementary data associated with this article can be found, in the online version, at http://dx.doi.org/10.1016/j.jcis.2014.07.008.

\section{References}

[1] R. Dong, J. Hao, Chem. Rev. 110 (2010) 4978.

[2] T.L. Greaves, C.J. Drummond, Chem. Soc. Rev. 37 (2008) 1709.

[3] M.J. Hollamby, K. Trickett, A. Mohamed, J. Eastoe, S.E. Rogers, R.K. Heenan, Langmuir 25 (2009) 12909.

[4] J.C. Liu, B.X. Han, G.Z. Li, Z.M. Liu, J. He, Fluid Phase Equilib. 187 (2001) 247.

[5] C. Seguin, J. Eastoe, R. Clapperton, R.K. Heenan, I. Grillo, Colloids Surf. A: Physicochem. Eng. Aspects 282 (2006) 134.

[6] C. Seguin, J. Eastoe, R.K. Heenan, I. Grillo, Langmuir 23 (2007) 4199.

[7] T. Warnheim, A.J. Jonsson, J. Colloid Interface Sci. 125 (1988) 627.

[8] Ö. Çelik, Ö. Dag, Angew. Chem. Int. Ed. 40 (2001) 3800.

[9] A.F. Demirörs, B.E. Eser, Ö. Dag, Langmuir 21 (2005) 4156.

[10] C. Albayrak, A. Cihaner, Ö. Dag, Chem. Eur. J. 18 (2012) 4190.

[11] C. Albayrak, N. Özkan, Ö. Dag, Langmuir 27 (2011) 870.

[12] L.Y. Zakharova, A.R. Ibragimova, F.G. Valeeva, L.A. Kudryavtseva, A.I. Konovalov, A.V. Zakharov, N.M. Selivanova, V.V. Osipova, M.V. Strelkov, Y.G. Galyametdinov, J. Phys. Chem. C 111 (2007) 13839.

[13] C. Rodriguez, H. Kunieda, Langmuir 16 (2000) 8263

[14] J.N. Sachs, T.B. Woolf, J. Am. Chem. Soc. 125 (2003) 8742.

[15] T. Inoue, Y. Yokoyama, L.Q. Zheng J. Colloid Interface Sci. 74 (2004) 349.

[16] M. Kahlweit, E. Lessner, R. Strey, J. Phys. Chem. 88 (1984) 1937.

[17] P. Firman, D. Haase, J. Jen, M. Kahlweit, R. Strey, Langmuir 1 (1985) 718

[18] M. Kahlweit, R. Strey, P. Firman, D. Haase, J. Jen, R. Schomaecker, Langmuir 4 (1988) 499.

[19] M. Kahlweit, R. Strey, R. Schomacker, D. Haase, Langmuir 5 (1989) 305.

[20] M. Kahlweit, R. Strey, D. Haase, J. Phys. Chem. 89 (1985) 163.

[21] T. Iwanaga, M. Suzuki, H. Kunieda, Langmuir 14 (1998) 5775.

[22] L.Q. Zheng, H. Minamikawa, K. Harada, T. Inoue, G.G. Chernik, Langmuir 19 (2003) 10487.

[23] C. Albayrak, G. Barım, Ö. Dag, Chem. Eur. J. 19 (2013) 15026.

[24] F. Hofmeister, Arch. Exp. Pathol. Pharmakol. 24 (1888) 247.

[25] F.E.M. Obrien, J. Sci. Instrum. Phys. Ind. 25 (1948) 73.

[26] L. Greenspan, J. Res. Natl. Bur. Stand. A, Phys. Chem. 81A (1976) 89.

[27] L.-J. Zhao, Y.-H. Zhang, L.-Y. Wang, Y.-A. Hu, F. Ding, Phys. Chem. Chem. Phys. 7 (2005) 2723.

[28] Y.-H. Zang, C.K. Chan, J. Phys. Chem. A 107 (2003) 5956.

[29] J.N. Pearce, A.F. Nelson, J. Am. Chem. Soc. 54 (1932) 3544

[30] C. Karakaya, Y. Türker, C. Albayrak, Ö. Dag Chem. Mater. 23 (2011) 3062.

[31] C. Karakaya, Y. Türker, Ö. Dag, Adv. Funct. Mater. 23 (2013) 4002.

[32] S.A. Burikov, T.A. Dolenko, P.A. Velikotnyi, A.V. Sugonyaev, V.V. Fadeev, Opt. Spectrosc. 98 (2005) 235

[33] P. Terpstra, D. Combes, A. Zwick, J. Chem. Phys. 92 (1990) 65. 